\title{
Appropriateness of colonoscopy in Europe (EPAGE II) Presentation of methodology, general results, and analysis of complications
}

Authors

Institutions
P. Juillerat ${ }^{1}$, I. Peytremann-Bridevaux ${ }^{2}$, J.-P. Vader $^{2}$, C. Arditi ${ }^{2}$, S. Schusselé Filliettaz ${ }^{2}$, R. W. Dubois ${ }^{3}$, J.-J. Gonvers' F. Froehlich ${ }^{1,4}$, B. Burnand ${ }^{2}$, V. Pittet $^{2}$

Institutions are listed at the end of article. submitted 17 June accepted after revision 15 December 2008

\section{Bibliography}

Dol $10.1055 / \mathrm{s}-0028-1119643$

Endoscopy 2009; 41:

240-246@ Georg Thieme

Verlag KG Stuttgart · New York ISSN 0013-726X

\section{Corresponding author} V. Pittet, PhD

Health Care Evaluation Unit Institute of Social and Preventive Medicine (IUMSP)

Centre Hospitalier Universitaire Vaudois and University of Lausanne

Rue du Bugnon 17

$\mathrm{CH}-1005$ Lausanne

Switzerland

Fax: +41-21-3144954

valerie.pittet@chuv.ch
Background and study aims: Appropriate use of colonoscopy is a key component of quality management in gastrointestinal endoscopy. In an update of a 1998 publication, the 2008 European Panel on the Appropriateness of Gastrointestinal Endoscopy (EPAGE II) defined appropriateness criteria for various colonoscopy indications. This introductory paper therefore deals with methodology, general appropriateness, and a review of colonoscopy complications.

Methods: The RAND/UCLA Appropriateness Method was used to evaluate the appropriateness of various diagnostic colonoscopy indications, with 14 multidisciplinary experts using a scale from 1 (extremely inappropriate) to 9 (extremely appropriate). Evidence reported in a comprehensive updated literature review was used for these decisions. Consolidation of the ratings into three appropriateness categories (appropriate, uncertain, inappropriate) was based on the median

\section{Background}

$\nabla$

Major progress in the accuracy and efficacy of diagnostic and therapeutic colonoscopy has been achieved over the last 30 years. Patient safety and comfort has increased with the advent of new endoscopic techniques $[1,2]$ and methods of sedation [3-5]. The number of colonoscopic procedures performed is steadily increasing, as indicated by a recent survey in the USA that has shown a three- to fourfold increase in the number of colonoscopies between 1998 and 2004 [6]. Colonoscopy is currently the most frequently performed gastroenterological endoscopic procedure in the USA [7]. This rapid growth in colonoscopy services can be partly attributed to the growing prevalence of colorectal cancer (CRC) screening [8]. An increase in the number of endoscopies performed has also been observed in Europe $[4,9]$. Colonoscopy may, however, be challenged in the future by other technologies such as com- and the heterogeneity of the votes. The experts then met to discuss areas of disagreement in the light of existing evidence, followed by a second rating round, with a subsequent third voting round on necessity criteria, using much more stringent criteria (i.e. colonoscopy is deemed mandatory).

Results: Overall, 463 indications were rated, with $55 \%, 16 \%$ and $29 \%$ of them being judged appropriate, uncertain and inappropriate, respectively. Perforation and hemorrhage rates, as reported in 39 studies, were in general $<0.1 \%$ and $<0.3 \%$, respectively

Conclusions: The updated EPAGE II criteria constitute an aid to clinical decision-making but should in no way replace individual judgment. Detailed panel results are freely available on the internet (www.epage.ch) and will thus constitute a reference source of information for clinicians.

puted tomography (CT) colonography (virtual colonoscopy) or wireless capsule endoscopy $[10,11]$, and indeed many studies have already compared the performance of colonoscopy with CT colonography [12-17].

Maximizing the appropriateness of healthcare interventions is a key component of quality care. The indication for an intervention is deemed appropriate when the expected benefits are greater than the expected risks or inconvenience to the patient by a sufficiently large margin that the intervention is worth performing. Assessment of appropriateness should ideally be based on highquality evidence; unfortunately, however, in many domains and for multiple clinical situations, the evidence base is poor or nonexistent. In such situations, an explicit multidisciplinary expert panel approach (the RAND/UCLA Appropriateness Method) has been used as a complement to evidence-based data $[18,19]$. This approach has previously been employed to establish 
appropriateness criteria in various clinical fields, such as coronarography [20], Crohn's disease treatment [21], or surgery [22,23]. The 2008 European Panel on the Appropriateness of Gastrointestinal Endoscopy, EPAGE II, constitutes a necessary update of the first gastrointestinal endoscopy panel criteria established in 1998 (EPAGE I) [24 - 40]. The appropriateness criteria developed in 1998 were widely used to assess the appropriateness or the over- and underuse of colonoscopy [37,41-44], and could be used as a decision support tool for general practitioners [45]. In addition, because appropriateness implies a balance between the expected benefits and risks for the patient, the best available evidence on risks of colonoscopy complications should be examined. The aim of this project was thus to update the EPAGE appropriateness criteria, using the methods described in this report together with an executive overview of the risk of the procedure, while the benefits are reported by cluster of diagnostic indications in companion articles [46-50].

\section{Methods}

$\nabla$

\section{The RAND/UCLA Appropriateness Method}

The same methodological approach as for the 1998 EPAGE I panel was used [18,38]. Briefly, a comprehensive literature review was undertaken (see below) to identify studies evaluating the benefits, effectiveness, safety, side effects, and possible complications of colonoscopy. A multidisciplinary panel of 14 European experts, who all have expertise in referral for or performance of colonoscopy was identified (Table e1): eight gastroenterologists, three primary care physicians and three surgeons. Four out of these 14 panelists were already familiar with the process as they had participated as panelists or organizers in EPAGE I.

A series of clinical indications was identified and categorized into 11 clinically relevant chapters corresponding to customary use of diagnostic colonoscopy. These chapters were: iron-deficiency anemia, hematochezia, nonspecific abdominal symptoms (uncomplicated lower abdominal pain and/or constipation and/or bloating), uncomplicated chronic diarrhea, evaluation of known inflammatory bowel disease (IBD), screening for colorectal cancer (CRC) in asymptomatic individuals and in IBD patients, surveillance after colonic polypectomy or after curative intent resection of CRC, and miscellaneous indications. A detailed description, including situations that were explicitly excluded from assessment, is shown in $\bullet$ Table 2.

\section{Literature review}

An update of the literature review was established, covering from 1997 to February 2008 (the previous literature review covered publications up to 1997), based on a three-step search strategy. First, a systematic search of Medline (1997 to February 2008) and the Cochrane Database was conducted to identify selected published guidelines, systematic reviews and/or meta-analyses, as well as primary studies assessing the use of colonoscopy in adults in the various clinical categories. Details of these OVID searches using Mesh words, keywords and specific limits are available online (Table e3). A comprehensive search of clinical and medical scientific websites issuing guidelines and recommendations for endoscopy was also performed. Details of websites that contributed useful information are available in Table e4. Finally, a complementary manual search was carried out based on the reference lists of retrieved guidelines, reviews and articles.
Only articles in English, French or German, and dealing with adults, were considered for this literature review. One search strategy aimed to collect information about risks and complications of colonoscopy and the results are reported here.

\section{Rating of clinical indications for appropriateness and necessity}

About 3 months before the panel meeting, the panel experts received the list of clinical indications, the literature review, and detailed instructions on how to rate the level of appropriateness of each indication. Given the very low risk of complications related to the procedure, as shown below, and complementing the usual definition of appropriateness, as indicated above, a modification of the definition of appropriateness was used: an indication was considered appropriate if there is a reasonable likelihood of a significant finding, if such a finding would alter therapy or prognosis, and if therapy would be beneficial. In rating the appropriateness of colonoscopy, panelists were asked to imagine a "typical" patient with the described set of clinical features receiving care from a "typical" physician performing the procedure. Financial considerations were not included in the judgment process at this stage. Costs, social and other related health technology evaluation features may be introduced at a later stage, i.e. when developing guidelines from appropriateness criteria. The experts used a scale graded from 1 to 9 to rate the appropriateness of each of the several hundred indications for which colonoscopy could, in practice or in theory, be considered, using the following scores: 1 =extremely inappropriate, 5 = uncertain, $9=$ extremely appropriate. The clinical indications were presented as a rating matrix which allowed a tabular presentation of the various scenarios by chapter. An indication for colonoscopy was considered appropriate if the median of the panelists' ratings was between 7 and 9, without disagreement, and inappropriate if the median was between 1 and 3, without disagreement. Scenarios with a median rating of 4 to 6 , or those revealing disagreement among the panelists, were considered "uncertain" as to the appropriateness of colonoscopy in such cases. Disagreement was defined as occurring when at least four panellists rated an indication from 1 to 3 and four others from 7 to 9. Fig. 1 displays an example of the rating matrix which was used by the experts. The first round of individual ratings were analysed and a telephone interview took place with each panelist to review potential problems with the indications rated, and to receive their suggestions for changes in the list of indications and the literature review.

The panel meeting took place in Montreux, Switzerland, over 2 days (April 17-19 2008). All chapters were discussed in the light of existing evidence that was summarized before the discussion and emphasized by the moderators, focusing on those indications for which there was disagreement between experts or uncertainty. A second round of ratings was then carried out during the panel meeting, followed by a third necessity rating round for those indications which were considered appropriate. An indication that the procedure was considered necessary fulfilled all of the following criteria [51]:

- The procedure is appropriate (that is, it must have a median rating of 7, 8 or 9 without disagreement at the second appropriateness rating round).

- It would be considered improper care or negligence not to provide this procedure.

- There is a reasonable chance that this procedure will benefit the patient. (A procedure could be deemed appropriate even if 
Table 2 EPAGE II: main clinical categories (chapters).

\begin{tabular}{|c|c|c|c|c|}
\hline \multirow[t]{2}{*}{ Chapter } & \multirow[t]{2}{*}{ Title } & \multirow[t]{2}{*}{ Situations explicitly excluded from assessment } & \multicolumn{2}{|c|}{ Number of clinical scenarios } \\
\hline & & & Round 1 & Round 2 \\
\hline 1 & Iron-deficiency anemia & $\begin{array}{l}\text { Malabsorption syndrome } \\
\text { Obvious cause of blood loss }\end{array}$ & 57 & 48 \\
\hline 2 & Hematochezia & $\begin{array}{l}\text { IBD } \\
\text { Hemodynamic instability }\end{array}$ & 24 & 54 \\
\hline 3 & $\begin{array}{l}\text { Lower abdominal symptoms (chronic } \\
\text { constipation/lower abdominal pain/ } \\
\text { bloating) }\end{array}$ & $\begin{array}{l}\text { Duration }<3 \text { months } \\
\text { Known IBD } \\
\text { FOBT-positive stools } \\
\text { Unexplained iron-deficiency anemia } \\
\text { Melena, hematochezia } \\
\text { Weight loss } \\
\text { Risk factors for CRC }\end{array}$ & 24 & 12 \\
\hline 4 & Uncomplicated diarrhea & $\begin{array}{l}\text { Acute diarrhea (<4 weeks) } \\
\text { Infectious origin } \\
\text { Malabsorption syndrome } \\
\text { Known IBD } \\
\text { Anemia/ bleeding } \\
\text { Laxative or sorbitol abuse } \\
\text { Risk factors for CRC } \\
\text { HIV/AIDS }\end{array}$ & 22 & 6 \\
\hline 5 & Evaluation of ulcerative colitis & $\begin{array}{l}\text { Prior colonoscopy } \\
\text { Cancer surveillance colonoscopy }\end{array}$ & 26 & 27 \\
\hline 6 & Evaluation of Crohn's disease & $\begin{array}{l}\text { Prior colonoscopy } \\
\text { Cancer surveillance colonoscopy }\end{array}$ & 28 & 23 \\
\hline 7 & Screening for CRC in known IBD & $\begin{array}{l}\text { Other specific colitides (or ileitis): } \\
\text { Infectious } \\
\text { Ischemic } \\
\text { Radiation } \\
\text { Microscopic colitis } \\
\text { Urogenital ulcer } \\
\text { Eosinophilic enteritis }\end{array}$ & 27 & 43 \\
\hline 8 & $\begin{array}{l}\text { Surveillance (follow-up colonoscopy) } \\
\text { after colonic polypectomy }\end{array}$ & $\begin{array}{l}\text { Symptomatic individuals } \\
\text { FAP } \\
\text { HNPCC (Lynch syndrome) } \\
\text { Hyperplastic polyposis }\end{array}$ & 84 & 77 \\
\hline 9 & $\begin{array}{l}\text { Surveillance after curative-intent resec- } \\
\text { tion of colorectal cancer }\end{array}$ & Palliation & 17 & 16 \\
\hline 10 & Screening for CRC & $\begin{array}{l}\text { Symptomatic individuals } \\
\text { Personal history of CRC } \\
\text { Personal history of polyps }\end{array}$ & 64 & 97 \\
\hline 11 & $\begin{array}{l}\text { Miscellaneous indications (lesion detect- } \\
\text { ed at recent barium enema or sigmoido- } \\
\text { scopy, preoperative colonoscopy, FOBT- } \\
\text { positive stools, fulminant colitis, steno- } \\
\text { sis in IBD, acute diverticulitis, endome- } \\
\text { triosis, unexplained weight loss, melena, } \\
\text { massive hematochezia, iron-deficiency } \\
\text { without anemia, hyperplastic polyps at } \\
\text { sigmoidoscopy) }\end{array}$ & All situations covered by other chapters & 40 & 60 \\
\hline Total & & & 413 & 463 \\
\hline
\end{tabular}

EPAGE II, 2008 European Panel on the Appropriateness of Gastrointestinal Endoscopy; CRC, colorectal cancer; FAP, familial adenomatous polyposis; FOBT, fecal occult blood test; HNPCC, hereditary nonpolyposis colorectal cancer (Lynch syndrome); IBD, inflammatory bowel disease.

it had a low likelihood of benefit but there were few risks; such procedures should not be considered necessary.)

- The benefit to the patient is not small. (A procedure could be considered appropriate if it had a minor, but almost certain benefit to the patient, but would not, however, be considered necessary.)
A general description of the results of the second round of ratings, including the proportion of appropriate, uncertain and inappropriate ratings, globally and by chapter, is reported here. Additional information about the variation in agreement in panel ratings between the first and second round of ratings was established. 


\begin{tabular}{|c|c|c|c|c|}
\hline \multicolumn{5}{|c|}{ Iron-deficiency anemia (malabsorption syndrome excluded) } \\
\hline & $\begin{array}{l}\text { No current } \\
\text { symptoms }\end{array}$ & $\begin{array}{l}\text { Upper abdominal } \\
\text { symptoms }\end{array}$ & $\begin{array}{l}\text { Lower abdominal } \\
\text { symptoms }\end{array}$ & $\begin{array}{l}\text { Scenario } \\
\text { Numbers }\end{array}$ \\
\hline \multicolumn{5}{|c|}{ Age $<50$, no risk factors for colorectal cancer } \\
\hline \multicolumn{5}{|c|}{ Men, OR women with gynecological cause excluded } \\
\hline No investigation done & 123456789 & 123456789 & 123456789 & $1-3$ \\
\hline \multicolumn{5}{|c|}{ Previous lower Gl investigation done (sigmoidoscopy, barium enema or both) } \\
\hline $\begin{array}{l}\text { Potential source of bleeding } \\
\text { eplaining IDA }\end{array}$ & 123456789 & 123456789 & 123456789 & $4-6$ \\
\hline $\begin{array}{l}\text { Potential source of bleeding } \\
\text { not identified }\end{array}$ & 123456789 & 123456789 & 123456789 & $7-9$ \\
\hline \multicolumn{5}{|c|}{ Previous upper $\mathrm{Gl}$ endocopy done } \\
\hline $\begin{array}{l}\text { Potential source of bleeding } \\
\text { eplaining IDA }\end{array}$ & 123456789 & 123456789 & 123456789 & $10-12$ \\
\hline $\begin{array}{l}\text { Potential source of bleeding } \\
\text { not identified }\end{array}$ & 123456789 & 123456789 & 123456789 & $13-15$ \\
\hline \multicolumn{5}{|l|}{$\begin{array}{l}\text { Women with gynecological } \\
\text { cause NOT excluded }\end{array}$} \\
\hline No investigation done & 123456789 & 123456789 & 123456789 & $16-18$ \\
\hline \multicolumn{5}{|c|}{ Previous lower Gl investigation done (sigmoidoscopy, barium enema or both) } \\
\hline $\begin{array}{l}\text { Potential source of bleeding } \\
\text { eplaining IDA }\end{array}$ & 123456789 & 123456789 & 123456789 & $19-21$ \\
\hline $\begin{array}{l}\text { Potential source of bleeding } \\
\text { not identified }\end{array}$ & 123456789 & 123456789 & 123456789 & $22-24$ \\
\hline \multicolumn{5}{|c|}{ Previous upper $\mathrm{Gl}$ endoscopy done } \\
\hline $\begin{array}{l}\text { Potential source of bleeding } \\
\text { eplaining IDA }\end{array}$ & 123456789 & 123456789 & 123456789 & $25-27$ \\
\hline $\begin{array}{l}\text { Potential source of bleeding } \\
\text { not identified }\end{array}$ & 123456789 & 123456789 & 123456789 & $28-30$ \\
\hline
\end{tabular}

Appropriateness scale: 1 = extremely inappropriate, 5 = uncertain, 9 = extremely appropriate

\section{Results}

$\nabla$

\section{Appropriateness and necessity ratings}

A total of 413 indications were submitted to the panelists for the first round of ratings. The analyses of the votes, experts' comments, and new evidence published during the process led to some slight modifications of the scenarios submitted for discussion by the panel and to the second round of ratings: 463 scenarios were rated by all experts, an increase of $11 \%$ on average. These indications were considered appropriate, uncertain, or inappropriate, in 255 (55\%), 73 (16\%), and 135 (29\%) of the clinical indications, respectively. 0 Table 5 presents these results by chapter of indications.

There was an increase in the proportion of agreement between panelists between the first and second round of ratings. Disagreement between experts and the percentage of uncertain indications decreased between round 1 and round 2 , from $15 \%$ to $9 \%$ and $23 \%$ to $16 \%$, respectively. Detailed results by category of indication are presented in the companion articles. A total of 255 appropriate ratings were evaluated for necessity; in 160 (63\%) a colonoscopy was considered necessary.

\section{Risks and complications of colonoscopy}

A total of 39 articles, published between 1997 and February 2008 and describing the complication rates of colonoscopy, were identified (Table e6) [1,2,52-88], including minor complications (i. e. abdominal pain or discomfort) or other negative outcomes (i.e.
Fig. 1 Rating matrix for the first round (example). Example for iron-deficiency anemia (extract showing scenarios 1-30). The symptoms evaluated are represented in columns. The scenarios are further described in detail, with color coding for greater clarity. In each box, values are shown on a 9-point scale. Appropriateness scale: 1 = extremely inappropriate; 5 = uncertain; 9 = extremely appropriate. 


\begin{tabular}{|c|c|c|c|c|c|}
\hline \multirow[t]{2}{*}{ Chapter* } & \multicolumn{2}{|c|}{ Scenarios } & \multicolumn{3}{|c|}{ Appropriateness, \% of scenarios } \\
\hline & Number & $\%$ of total & Appropriate & Uncertain & Inappropriate \\
\hline 1 & 48 & 10 & 58 & 27 & 15 \\
\hline 2 & 54 & 11 & 83 & 13 & 4 \\
\hline 3 & 12 & 3 & 42 & 25 & 33 \\
\hline 4 & 6 & 1 & 67 & 0 & 33 \\
\hline 5 & 27 & 6 & 41 & 4 & 55 \\
\hline 6 & 23 & 5 & 30 & 30 & 40 \\
\hline 7 & 43 & 9 & 47 & 19 & 35 \\
\hline 8 & 77 & 17 & 56 & 7 & 38 \\
\hline 9 & 16 & 4 & 63 & 25 & 12 \\
\hline 10 & 97 & 21 & 51 & 20 & 29 \\
\hline 11 & 60 & 13 & 53 & 10 & 37 \\
\hline Total & 463 & 100.0 & 55 & 16 & 29 \\
\hline
\end{tabular}

Table 5 EPAGE II appropriateness results by main clinical categories (chapters).

EPAGE II, 2008 European Panel on the Appropriateness of Gastrointestinal Endoscopy

* For complete chapter titles see Table 2 .

\section{Conclusion}

\section{$\nabla$}

An update of the EPAGE appropriateness criteria for the use of colonoscopy was undertaken in the spring of 2008. The majority of the indications rated were considered appropriate, whereas about a third were considered inappropriate. The panel meeting led to enhanced agreement between panelists and, indeed, disagreement decreased to less than $10 \%$ and the proportion of uncertain indications was reduced by a third. For almost two-thirds of the indications rated as appropriate, the experts considered that colonoscopy was necessary. Given the large number of indications considered by the panel, tabular presentation is not feasible. A presentation by chapter, according to the constituent characteristics of the clinical indications, is, however, available in a convenient internet presentation. Answering a small number of questions allows the physician to determine, in a few simple steps, the degree of appropriateness of colonoscopy for any clinical indication (www.epage.ch).

It is difficult to assess complications of colonoscopy precisely, since there is no consensus on the definition of what constitutes a complication. While accurate data may be, and often are, obtained for severe and acute complications, the extent of delayed and/or minor complications is probably underestimated because of underreporting and the difficulties entailed in data collection. There are also minimal data for minor adverse events, and indirect negative outcomes such as work days lost secondary to colonoscopy, are rarely considered and recorded.

\section{Acknowledgments \\ $\nabla$}

The authors gratefully acknowledge the selfless commitment and invaluable contribution of the expert panel members, who made this project possible: Lars Agréus (SE), Christoph Beglinger $(\mathrm{CH})$, Peter Bytzer (DK), Michel Delvaux (FR), Volker F. Eckardt (DE), Peter D. Fairclough (UK), François Lacaine (FR), Olivier Le Moine (BE), Vicente Lorenzo-Zúñiga Garcia (ES), Giorgio Minoli (IT), Mattijs E. Numans (NL), Daniel Oertli (CH), John O'Malley (UK), Alastair Windsor (UK). The authors warmly thank Susan Giddons for her valuable assistance in the administration of the expert panel process, as well as in the meticulous preparation of the manuscripts.
This work was supported by a grant from the Loterie Romande, Switzerland $(\mathrm{CH})$.

Competing interests: None

\section{Appendix: The EPAGE II Study Group}

$\nabla$

See page 205 .

\section{Institutions}

1 Department of Gastroenterology and Hepatology, Centre Hospitalier Universitaire Vaudois and University of Lausanne, Lausanne, Switzerland

2 Healthcare Evaluation Unit, Institute of Social and Preventive Medicine

(IUMSP), Centre Hospitalier Universitaire Vaudois and University of Lausanne, Lausanne, Switzerland

Cerner LifeSciences, Beverly Hills, USA

${ }^{4}$ Department of Gastroenterology, University of Basle, Basle, Switzerland

\section{References}

1 Misra T, Lalor E, Fedorak RN. Endoscopic perforation rates at a Canadian university teaching hospital. Can J Gastroenterol 2004; 18: 221 - 226

2 Viiala CH, Zimmerman M, Cullen DJ, Hoffman NE. Complication rates of colonoscopy in an Australian teaching hospital environment. Intern Med J 2003; 33: 355 - 359

3 Froehlich F, Harris JK, Wietlisbach Vet al. Current sedation and monitoring practice for colonoscopy: an International Observational Study (EPAGE). Endoscopy 2006; 38: 461 - 469

4 Heuss LT, Froehlich F, Beglinger $C$. Changing patterns of sedation and monitoring practice during endoscopy: results of a nationwide survey in Switzerland. Endoscopy 2005; 37: 161 - 166

5 Rex DK, Overley C, Kinser K et al. Safety of propofol administered by registered nurses with gastroenterologist supervision in 2000 endoscopic cases. Am J Gastroenterol 2002; 97: 1159-1163

6 Cohen LB, Wecsler JS, Gaetano JN et al. Endoscopic sedation in the United States: results from a nationwide survey. Am J Gastroenterol 2006; 101: $967-974$

7 Sonnenberg A, Amorosi SL, Lacey MJ, Lieberman DA. Patterns of endoscopy in the United States: analysis of data from the Centers for Medicare and Medicaid Services and the National Endoscopic Database. Gastrointest Endosc 2008; 67: 489-496

8 Harewood GC, Lieberman DA. Colonoscopy practice patterns since introduction of medicare coverage for average-risk screening. Clin Gastroenterol Hepatol 2004; 2: $72-77$

9 Froehlich F, Gonvers JJ, Fried M. Conscious sedation, clinically relevant complications and monitoring of endoscopy: results of a nationwide survey in Switzerland. Endoscopy 1994; 26: 231 - 234

10 May A, Manner H, Schneider M et al. Prospective multicenter trial of capsule endoscopy in patients with chronic abdominal pain, diarrhea 
and other signs and symptoms (CEDAP-Plus Study). Endoscopy 2007; 39: $606-612$

11 Mergener K, Ponchon T, Gralnek I et al. Literature review and recommendations for clinical application of small-bowel capsule endoscopy, based on a panel discussion by international experts. Consensus statements for small-bowel capsule endoscopy, 2006/2007. Endoscopy 2007; 39: 895-909

12 Cotton PB, Durkalski VL, Pineau BC et al. Computed tomographic colonography (virtual colonoscopy): a multicenter comparison with standard colonoscopy for detection of colorectal neoplasia. JAMA 2004; 291: $1713-1719$

13 Johnson CD, Toledano AY, Herman BA et al. Computerized tomographic colonography: performance evaluation in a retrospective multicenter setting. Gastroenterology 2003; 125: 688-695

14 Kim DH, Pickhardt PJ, Taylor AJ et al. CT colonography versus colonoscopy for the detection of advanced neoplasia. N Engl J Med 2007; 357: $1403-1412$

15 Pickhardt PJ, Choi JR, Hwang I et al. Computed tomographic virtual colonoscopy to screen for colorectal neoplasia in asymptomatic adults. N Engl J Med 2003; 349: 2191 - 2200

16 Rex DK, Lieberman D. ACG colorectal cancer prevention action plan: update on CT-colonography. Am J Gastroenterol 2006; 101: 1410 1413

17 Rockey DC, Paulson E, Niedzwiecki D et al. Analysis of air contrast barium enema, computed tomographic colonography, and colonoscopy: prospective comparison. Lancet 2005; 365: 305-311

18 Brook RH, Chassin MR, Fink A et al. A method for the detailed assessment of the appropriateness of medical technologies. Int J Technol Assess Health Care 1986; 2: 53-63

19 Naylor CD. What is appropriate care? N Engl J Med 1998; 338: 1918 1920

20 Bernstein SJ, Hilborne LH, Leape LL et al. The appropriateness of use of coronary angiography in New York State. JAMA 1993; 269: 766 - 769

21 Vader JP, Froehlich F, Juillerat P et al. Appropriate treatment for Crohn's disease: methodology and summary results of a multidisciplinary international expert panel approach - EPACT. Digestion 2006; 73: 237 248

22 Park RE, Fink A, Brook RH et al. Physician ratings of appropriate indications for six medical and surgical procedures. Am J Public Health 1986; 76: $766-772$

23 Vader JP, Porchet F, Larequi-Lauber $T$ et al. Appropriateness of surgery for sciatica: reliability of guidelines from expert panels. Spine 2000 25: $1831-1836$

24 Bochud M, Burnand B, Froehlich F et al. 12. Appropriateness of colonoscopy: surveillance after polypectomy. Endoscopy 1999; 31: 654-663

25 Bochud M, Burnand B, Froehlich F et al. 13. Appropriateness of colonoscopy: surveillance after curative resection of colorectal cancer. Endoscopy 1999; 31: 664-672

26 Bochud M, Gonvers JJ, Vader JP et al. 2. Appropriateness of gastroscopy: gastro-esophageal reflux disease. Endoscopy 1999; 31: 596-603

27 Bochud M, Gonvers JJ, Vader JP et al. 3. Appropriateness of gastroscopy: Barrett's esophagus. Endoscopy 1999; 31: 604-610

28 Burnand B, Bochud M, Froehlich F et al. 14. Appropriateness of colonoscopy: screening for colorectal cancer in asymptomatic individuals. Endoscopy 1999; 31: 673-683

29 De Bosset V, Gonvers JJ, Burnand B et al. 7. Appropriateness of colonoscopy: iron-deficiency anemia. Endoscopy 1999; 31: 627-630

30 De Bosset V, Gonvers JJ, Froehlich F et al. 5. Appropriateness of gastroscopy: bleeding and dysphagia. Endoscopy 1999; 31: 615-622

31 De Bosset V, Gonvers JJ, Vader JP et al. 9. Appropriateness of colonoscopy: lower abdominal pain or constipation. Endoscopy 1999; 31: $637-$ 640

32 Froehlich F, Bochud M, Gonvers JJ et al. 1. Appropriateness of gastroscopy: dyspepsia. Endoscopy 1999; 31: 579-595

33 Froehlich F, Gonvers JJ, Vader JP et al. Appropriateness of gastrointestinal endoscopy: risk of complications. Endoscopy 1999; 31: 684-686

34 Froehlich F, Larequi-Lauber T, Gonvers JJ et al. 11. Appropriateness of colonoscopy: inflammatory bowel disease. Endoscopy 1999; 31: 647 653

35 Gonvers JJ, De Bosset V, Froehlich F et al. 8. Appropriateness of colonoscopy: hematochezia. Endoscopy 1999; 31: 631-636

36 Gonvers JJ, de Bosset V, Vader JP et al. 6. Appropriateness of gastroscopy: risk factors for gastric cancer. Endoscopy 1999; 31: 623-626
37 Gonvers JJ, Harris JK, Wietlisbach V et al. A European view of diagnostic yield and appropriateness of colonoscopy. Hepatogastroenterology 2007; 54: 729-735

38 Vader JP, Burnand B, Froehlich F et al. The European Panel on Appropriateness of Gastrointestinal Endoscopy (EPAGE): project and methods. Endoscopy 1999; 31: $572-578$

39 Vader JP, Froehlich F, Dubois RW et al. European Panel on the Appropriateness of Gastrointestinal Endoscopy (EPAGE): conclusion and WWW site. Endoscopy 1999; 31: 687-694

40 Vader JP, Larequi-Lauber T, Froehlich $F$ et al. 4. Appropriateness of gastroscopy: atypical chest pain. Endoscopy 1999; 31: 611-614

41 Burnand B, Harris JK, Wietlisbach V et al. Use, appropriateness, and diagnostic yield of screening colonoscopy: an international observational study (EPAGE). Gastrointest Endosc 2006; 63: 1018-1026

42 Harris JK, Froehlich F, Gonvers JJ et al. The appropriateness of colonoscopy: a multi-center, international, observational study. Int J Qual Health Care 2007; 19: 150 - 157

43 Vader JP, Pache I, Froehlich Fet al. Overuse and underuse of colonoscopy in a European primary care setting. Gastrointest Endosc 2000; 52: $593-599$

44 Vader JP, Wietlisbach V, Harris JK et al. Gastroenterologists overestimate the appropriateness of colonoscopies they perform: an international observational study. Endoscopy 2005; 37: 840 - 846

45 Terraz O, Wietlisbach V, Jeannot JG et al. The EPAGE internet guideline as a decision support tool for determining the appropriateness of colonoscopy. Digestion 2005; 71: $72-77$

46 Arditi C, Gonvers JJ, Burnand B et al. Appropriateness of colonoscopy in Europe (EPAGE II) Surveillance after polypectomy and after resection of colorectal cancer. Endoscopy 2009; 41: 209-217

47 Arditi C, Peytremann-Bridevaux I, Burnand B et al. Appropriateness of colonoscopy in Europe (EPAGE II) Screening for colorectal cancer. Endoscopy 2009; 41: 200-208

48 Peytremann-Bridevaux I, Arditi C, Froehlich F et al. Appropriateness of colonoscopy in Europe (EPAGE II) Iron-deficiency anemia (IDA) and hematochezia. Endoscopy 2009; 41: 227 - 233

49 Schusselé Filliettaz S, Gonvers JJ, Peytremann-Bridevaux I et al. Appropriateness of colonoscopy in Europe (EPAGE II) Functional bowel disorders: pain, constipation and bloating. Endoscopy 2009; 41: 234-239

50 Schusselé Filliettaz S, Juillerat P, Burnand B et al. Appropriateness of colonoscopy in Europe (EPAGE II) Chronic diarrhea and known inflammatory bowel disease. Endoscopy 2009; 41: 218-226

51 Kahan JP, Bernstein SJ, Leape LL et al. Measuring the necessity of medical procedures. Med Care 1994; 32: 357-365

52 Anderson ML, Pasha TM, Leighton JA. Endoscopic perforation of the colon: lessons from a 10-year study. Am J Gastroenterol 2000; 95: 3418 3422

53 Araghizadeh FY, Timmcke AE, Opelka FG et al. Colonoscopic perforations. Dis Colon Rectum 2001; 44: 713-716

54 Arora A, Singh P. Colonoscopy in patients 80 years of age and older is safe, with high success rate and diagnostic yield. Gastrointest Endosc 2004; 60: 408-413

55 Bini EJ, Firoozi B, Choung RJ et al. Systematic evaluation of complications related to endoscopy in a training setting: a prospective 30 -day outcomes study. Gastrointest Endosc 2003; 57: 8-16

56 Bowles CJ, Leicester R, Romaya C et al. A prospective study of colonoscopy practice in the UK today: are we adequately prepared for national colorectal cancer screening tomorrow? Gut 2004; 53: 277-283

57 Canard JM, Debette-Gratien M, Dumas R et al. A prospective national study on colonoscopy and sigmoidoscopy in 2000 in France. Gastroenterol Clin Biol 2005; 29: 17-22

58 Cobb WS, Heniford BT, Sigmon LB et al. Colonoscopic perforations: incidence, management, and outcomes. Am Surg 2004; 70: 750 - 757; discussion 757-758

59 Cotton PB, Connor P, McGee D et al. Colonoscopy: practice variation among 69 hospital-based endoscopists. Gastrointest Endosc 2003; 57: $352-357$

60 Dafnis G, Ekbom A, Pahlman L, Blomqvist P. Complications of diagnostic and therapeutic colonoscopy within a defined population in Sweden. Gastrointest Endosc 2001; 54: 302 - 309

61 Denis B, Ben Abdelghani M, Peter A et al. [Two years of mortality and morbidity conferences in a hospital gastrointestinal endoscopy unit]. Gastroenterol Clin Biol 2003; 27: 1100-1104

62 Denis B, Weiss AM, Peter A et al. Quality assurance and gastrointestinal endoscopy: an audit of 500 colonoscopic procedures. Gastroenterol Clin Biol 2004; 28: 1245-1255 
63 Duncan JE, Sweeney WB, Trudel JL et al. Colonoscopy in the elderly: low risk, low yield in asymptomatic patients. Dis Colon Rectum 2006; 49: 646-651

64 Eckardt VF, Kanzler G, Schmitt T et al. Complications and adverse effects of colonoscopy with selective sedation. Gastrointest Endosc 1999; 49: $560-565$

65 Fasoli R, Repaci G, Comin U, Minoli G. A multi-centre North Italian prospective survey on some quality parameters in lower gastrointestinal endoscopy. Dig Liver Dis 2002; 34: 833-841

66 Gangi S, Saidi F, Patel K et al. Cardiovascular complications after GI endoscopy: occurrence and risks in a large hospital system. Gastrointest Endosc 2004; 60: 679-685

67 Gatto NM, Frucht H, Sundararajan Vet al. Risk of perforation after colonoscopy and sigmoidoscopy: a population-based study. J Natl Cancer Inst 2003; 95: 230-236

68 Heldwein $W$, Dollhopf $M$, Rosch $T$ et al. The Munich Polypectomy Study (MUPS): prospective analysis of complications and risk factors in 4000 colonic snare polypectomies. Endoscopy 2005; 37: 1116-1122

69 Karajeh MA, Sanders DS, Hurlstone DP. Colonoscopy in elderly people is a safe procedure with a high diagnostic yield: a prospective comparative study of 2000 patients. Endoscopy 2006; 38: 226-230

$70 \mathrm{Ko} C W$, Riffle S, Shapiro JA et al. Incidence of minor complications and time lost from normal activities after screening or surveillance colonoscopy. Gastrointest Endosc 2007; 65: 648-656

71 Korman $L Y$, Overholt BF, Box T, Winker CK. Perforation during colonoscopy in endoscopic ambulatory surgical centers. Gastrointest Endosc 2003; 58: $554-557$

72 Levin TR, Zhao W, Conell C et al. Complications of colonoscopy in an integrated health care delivery system. Ann Intern Med 2006; 145: 880886

73 Luning TH, Keemers-Gels ME, Barendregt WB et al. Colonoscopic perforations: a review of 30366 patients. Surg Endosc 2007; 21: $994-997$

74 Ma WT, Mahadeva S, Kunanayagam S et al. Colonoscopy in elderly Asians: a prospective evaluation in routine clinical practice. J Dig Dis 2007; 8: 77-81

75 Nelson DB, McQuaid KR, Bond JH et al. Procedural success and complications of large-scale screening colonoscopy. Gastrointest Endosc 2002; 55: 307-314

76 Newcomer MK, Shaw MJ, Williams DM, Jowell PS. Unplanned work absence following outpatient colonoscopy. J Clin Gastroenterol 1999; 29: $76-78$

77 Rathgaber SW, Wick TM. Colonoscopy completion and complication rates in a community gastroenterology practice. Gastrointest Endosc 2006; 64: 556-562
78 Sardinha TC, Nogueras IJ, Ehrenpreis ED et al. Colonoscopy in octogenarians: a review of 428 cases. Int J Colorect Dis 1999; 14: 172- 176

79 Sharma VK, Nguyen CC, Crowell MD et al. A national study of cardiopulmonary unplanned events after GI endoscopy. Gastrointest Endosc 2007; 66: $27-34$

80 Sieg A, Hachmoeller-Eisenbach U, Eisenbach T. Prospective evaluation of complications in outpatient GI endoscopy: a survey among German gastroenterologists. Gastrointest Endosc 2001; 53: 620-627

81 Sieg A, Theilmeier A. [Results of coloscopy screening in 2005 - an Internet-based documentation]. Dtsch Med Wochenschr 2006; 131: 379 383

82 Taku K, Sano Y, Fu KI et al. Iatrogenic perforation associated with therapeutic colonoscopy: a multicenter study in Japan. J Gastroenterol Hepatol 2007; 22: 1409-1414

83 Tran DQ Rosen L, Kim R et al. Actual colonoscopy: what are the risks of perforation?. Am Surg 2001; 67: 845-847; discussion 847-848

84 Tulchinsky H, Madhala-Givon O, Wasserberg $\mathrm{N}$ et al. Incidence and management of colonoscopic perforations: 8 years' experience. World J Gastroenterol 2006; 12: 4211 - 4213

85 Wexner SD, Forde KA, Sellers $G$ et al. How well can surgeons perform colonoscopy? Surg Endosc 1998; 12: 1410-1414

86 Wexner SD, Garbus JE, Singh JJ. A prospective analysis of 13580 colonoscopies. Reevaluation of credentialing guidelines. Surg Endosc 2001; $15: 251-261$

87 Zerey M, Paton BL, Khan PD et al. Colonoscopy in the very elderly: a review of 157 cases. Surg Endosc 2007; 21: 1806-1809

88 Zubarik R, Fleischer DE, Mastropietro C et al. Prospective analysis of complications 30 days after outpatient colonoscopy. Gastrointest Endosc 1999; 50: 322 - 328

89 Imperiale TF, Wagner DR, Lin CY et al. Risk of advanced proximal neoplasms in asymptomatic adults according to the distal colorectal findings. N Engl J Med 2000; 343: 169-174

90 Lieberman DA, Weiss DG, Bond JH et al. Use of colonoscopy to screen asymptomatic adults for colorectal cancer. Veterans Affairs Cooperative Study Group 380. N Engl J Med 2000; 343: 162 - 168

The following tables are available online: www.thieme-connect.com/media/endoscopy/200903/supmat/ endo845.pdf

Table e1 EPAGE II experts.

Table e3 MeSH words/keywords for Medline searches and limits. Table e4 Relevant websites.

Table e6 Complication rates of colonoscopy reported in 39 studies. 